\title{
Cleft Lip and Palate
}

\author{
by
}

D. H. WALKER. F.R.C.S.(Ed.)

Plastic Surgeon, Johannesburg Hospital and

University of the Witwatersrand.

At least one in every thousand babies born will have a hare lip or cleft palate, or both. To have some idea of how to treat and repair these is not enough; the immediate method is of little value unless one tries to assess its possible effects on the life and behaviour of a young adult twenty years hence.

There is a quotation attributed to Professor T. P. Kilner and used by Sir Harold Gillies which epitomises the ideal end result - "they shall look well, speak well and eat well."

It is unlikely that any one person can acquire and use all the skill, judgement and art needed to approach this ideal end-result.

The methods used at present are in the hands of three groups of people:-

(1) Plastic Surgeons and Nurses.

(2) Orthodontists.

(3) Speech Therapists.

These are not given in any order of importance or priority but rather in a possible order of consultation. Each is important in his or her own field and at a particular time - in the progress of treatment, any member may have top priority in helping the patient.

It is our practice, whenever possible, to see the baby with cleft lip and/or palate on the day of birth or soon after. Once a probable treatment plan has been laid down, the parents can be told of all the positive help that can be given to their son or daughter.

It is known that about $20 \%$ of all cleft lip and palate patients have a family history of this anomaly; this should be recorded and constantly kept in mind. The help and advice of a skilled geneticist may be sought if a larger family is to be planned with reasonable safety in this group.

Of the remaining $80 \%$, a large proportion is associated with poor living conditions or malnutrition - either immediate or in the past. The usual speculative factors of virus and other infections are quoted. However, a strong case may be deduced for the grave dangers of the use of steroids during the first three months of pregnancy. These substances need very special indications for their use and should probably be ordered for a pregnant woman only by doctors in consultation.

All classifications are man-made and usually false in many respects. Rigid classifications of natural phenomena are perhaps as good an indictment as any of the great mental trap of mankind - man's pathetic and frequent belief in the infallibility of his own reasoning.

Different centres and different countries use varying, variable and often conflicting classifications. It is suggested that a brief accurate description is one of the best forms of classification.

\section{CLEFT OR HARE LIP.}

(a) Unilateral or Bilateral.

(b) Incomplete or Complete.

\section{CLEFT PALATE.}

(a) Complete or Incomplete. (The latter sometimes referred to as a pssterior cleft of varying degree).

(b) Unilateral or Bilateral.

For example.

\section{Hendrik v.d. Merwe.}

Unilateral complete cleft lip (L).

Palate intact, notched alveolus.

\section{John Smith.}

Bilateral cleft lip and palate.

(L) lip cleft: incomplete.

(R) lip cleft: complete.

Permutations of these allow for all but the rare anomalies. The extra writing of a few words is more than worth the extra clarity of the mental picture produced for any one who is at all familiar with the appearance of children with clefts.

There is little, if any, room for the concept of repair of a cleft lip or palate as an 
emergency procedure. When this form of request is made it generally relates to feeding difficulties. These can nearly always be overcome by (a) breastfeeding the baby as much as possible to encourage a normal sucking reflex, (b) completing the extra requirements by using a feeding bottle with a suitable teat.

There are many examples of children growing to be well developed and articulate adults without any surgical procedures or any other treatment of their cleft lips and palates. One has recently seen an adult male with an untreated bilateral cleft lip and palate who is eighty-five years old. A further patient with not so severe a disability is a woman over sixty years old who has an untreated, wide cleft palate extending the whole length from the post-alveolar region to the uvula. This woman has perfectly intelligible speech and, although when young had difficulty in preventing certain foods and fluids from escaping via her nose, now has learnt to control this abnormality completely and eats and drinks in an exemplary manner. She has three female grandchildren, all of whom have identical clefts to her own, and informs us that this is a common abnormality in all female members of her family but is not found in the males. The eldest of the three grandchildren has already had her palate repaired and now rejoices in normal speech.

To return to the question of early operation: one does occasionally repair, under local anaesthesia in the maternity hospital, a partial cleft lip of moderate degree - generally when the palate is intact and the lip presents the only defect. The patient should be about a week old and in excellent health.

Our more usual procedure is to ask the Orthodontist to see a child with cleft lip and/ or palate in the maternity hospital during the

$\therefore$ first week of life. It is possible with modern techniques, skill and materials to take dental impressions at this early stage and to make an accurately fitting prosthesis or obturator which closes at least the front of the cleft in the gum and palate completely. This is held in position by a light headcap which is attached by rubber bands to smooth, light, curved wires which project to the exterior from the small plate in the baby's mouth. With a little patient, gentle and persistent replacement the baby soon accepts the ap- pliance and feeds quite readily with it in position.

The object of this is to produce a better, more even alignment of the parts of the alveolus on either side of the cleft. Not only will this, after a few months, make the operation easier and more successful, but it will improve the exteinal contour and, internally, pave the way for a better palate repair.

The success of such an appliance is largely contributed to by the child, since persistent palatal and facial movements such as occur in sucking, perform a strong and almost continuous moulding action, transmitted by the orthodontic appliance. It has been found, however, that there may be a rapid decrease in the degree of spectacular improvement if the method is not started in the first three months of life.

After many years of argument and evidence, world authorities are still undecided as to the best age for surgical treatment.

A general method for cleft lip is to choose any age over three months, or when the child weighs about twelve pounds or more and is in good health and gaining weight steadily. It is preferable for the child to be on a mixed diet.

The presence of early erruption of teeth is not a bar to any of the usual standard operations. Some teeth, badly out of position "ectopic teeth" as they are called, may be safely removed at the operation for repair of the lip.

The essentials of this operation are best considered in the form of priciples - there are dozens of technical variations in actual operative procedure - all aiming at the same end-result: a lip which on close inspection looks as though the patient once had an accident in the form of a cut lip (and possibly cut nostril floor) which has left a faint scar.

The important points to look for are:-

(i) That the nostril bases are on the same horizontal line and the nostril floors from nostril margin to the septum are of the same width.

(ii) That the sides of the cleft are of the same length and hence the depth of lip below each nostril is the same on both sides. 
(iii) That the muco-cutaneous junction (i.e. the junction of the skin and red margin) form a smooth continuous line, without "steps" and with the same depth of mucous membrane showing on both sides. There may or may not be a "cupid's bow".

A large number of surgeons' names are attached to the operations described for repairing hare lips - all aim at the results described. Some of the more common names are Mirault, Blair, Kilner, Rose, Le Mesurier, Veau, Tennison, and, more recently, Millard.

It is, in the end result, most important to avoid a "tight lip" — stretched from side to side.

Incidentally, a device preventing unreasonable side pull on recently inserted stitches is called a "Logan's Bow" and consists of a smooth U-shaped piece of metal fastened to the cheek by adhesive strapping so that it rests astride the newly repaired lip and relaxes the margins of the cleft.

Stitches remain in for a varying period, depending on tension and other factors, but most are out within a week. The patient is usually in hospital for about ten days.

Whenever possible some part of the gap in the gum and the nostril floor are repaired at the same time as the lip.

A suitable age for cleft palate surgery is of ten considered to be between one and two years. At this age the child is beginning to make sounds which have a definite meaning and, as the end of the second year approaches to say simple words in imitation of adults and older children.

Surgical repair at this stage is done partly on the basis of the theory that learning to speak with a closed palate (rather than an open, unrepaired one) will produce fewer bad speech habits and their subsequent imprinting on the child's mind will be minimal, and partly to aid in normal eating.

Against repair at this time are the findings of a number of workers - including those engaged in a long term survey for the American Orthodontic Association. Follow ups of the order: of twenty years have been done on patients who had radical repairs of cleft palates in the first year or two of life. Many of these operations featured a very radical separation of soft parts from bone in the preceding lip repair as well as in the later palate repair. This usually takes the form of elevating as much of the lining as possible of both nasal and oral surfaces of the bony palatal shelves, so that soft parts may be moved towards the midline to close the cleft, and also displaced backwards to give length and mobility to the repaired palate.

It is believed that this may, in some cases contribute towards severely retarded development of the middle third of the face, becoming most noticeable as adult life is approached. This is not, of course, conclusive evidence that the radical nature of the operation in the cases investigated was the direct and entire cause of the mal-development of the face and the palate. Firstly the term "radical" must' be qualified by knowing exactly the extent and technical nature of the dissection at the operation. Secondly, the abnormality of a cleft palate may include anomalies of the blood supply and irregularities in the growth centres of the bones of the face - in number, position or behaviour or in combinations of any of these.

Of major importance in the growth of the centre of the face in a forward direction, is the nasal Septum, based in turn on the Vomer, a bone which resembles a vertical partition, rising high in the naso-pharynx from the base of the skull. Interference with the blood supply of the Vomer may result in failure of the tip of the nose and upper lip to grow forward sufficiently - hence the occasional flat profile of the repaired upper lip. This deformity is sometimes contributed to by a slow inward collapse of the alveolar arches with a final contour that is small and pointed towards the front.

As the information just outlined was collected it became important to know when, if the age of two years is too early, it might be reasonably safe to operate on a growing face in a relatively radical manner. It is now suggested that sufficient growth of the middle region of the facial skeleton has taken place by about the age of four years to minimize the risk of serious facial deformity after operation. Nevertheless one should remember that there is no finality in this matter and the exact age for operation is often varied for different patients.

If the child is intelligent enough to try and 
use recognisable words before operation there should be a period of meetings with the speech therapist, frequent enough to develop friendly contact and confidence. This should culminate in a careful, unhurried tape recording and pre-operative speech assessment.

General health before operation must be good and examination should show the child to be free of any other gross abnormality. It is not uncommon for congenital defects to occur together in the same patient, e.g. an abnormal heart, a hernia or a genito-urinary abnormality. These, or any other defects, do not as a rule prevent successful treatment of cleft lip and palate.

From a Plastic Surgeon's point of view, one aim stands head and shoulders above the rest - Normal Speech. In order to promote the highest standards of work this aim should be taken literally. The best results should produce speech indistinguishable from that accepted in persons who have no cleft palate.

It is believed that the anatomical and physiological factors contributing to normal speech include an active closing off of the oro-pharynx from the naso-pharynx while speaking. The main aid to this is probably a long, mobile soft palate capable of brisk, symmetrical muscle contraction. As he commences the operation by mobilising the soft parts and testing their displacement backwards and towards the mid-line, this thought must be uppermost in the surgeon's mind.

As the dissection progresses each step should lead to a repair which consists, if possible, of a complete closure, using the patient's tissue in such a way that no artificial device will be needed later and no fistulae will remain or develop.

At most, one's compromise on this arrangement should consist of an occasional case with a temporary obturator and the intention of planned fistula closure later.

The application of these principles is made clearer by reference to the common types of cleft (the simplest first) and very brief descriptions of the operations commonly used in their repair.

\section{A. CLEFT SOFT PALATE ONLY.}

Sometimes referred to as a "posterior cleft" this may vary from a bifid uvula to the whole length of the soft palate ending in a V-shaped notch in the back edge of the bony hard palate. This latter deformity can be felt by gently putting a finger in the child's mouth.

The older operation for the repair of this is associated with the name of Langenbeck and consists of excising the edges of the cleft facing each other and thus displaying two layers of mucous membrane in a "sandwich-formation" with muscle as the filling on each side of the cleft. Next a long incision is made in the soft and hard palate on the inner side of the teeth of the upper jaw. The extent of these incisions, on each side, is from the hamulus to the level of the canine tooth.

The soft parts on either side of the cleft are then lifted cleanly off the bone and the greater palatine artery is carefully exposed on the underside of each strap-like flap. If the two strap-like flaps - attached back and front - have been sufficiently mobilised and the cleft is not too wide, they may be sewn together in the midline with two layers of stitches - one on the nasal side and one on the mouth side with the knots facing down into the mouth from the newly constituted roof. One of these layers of stitches should include muscle as it passes through the edges.

If the cleft is wide and the greater palatine artery acts as a tethering mechanism under the flap, this may be divided without serious complications. What does produce serious complications is suturing under tension - this must be avoided.

The disadvantages of the Langenbeck operation are that it does not guarantee permanent lengthening of the palate as the raw undersurfaces of the flaps may scar, shrink and contract in the weeks and months following the operation and so pull forward the uvula and back edge of the soft palate. This minimises the chances of good closing off of the naso-pharynx and hence makes normal speech more difficult.

It is, in any case, difficult to be sure of what one has achieved on the speech side for at least three months after operation and sometimes not for a year or more.

The name of Victor Veau, a French sur- 
geon is sometimes associated with the operation which uses two long flaps in repair of a cleft palate, at first resembling von Langenbeck's flaps, but dividing the front attachments of these flaps so that they are only living on their attachments to the soft palate. Backward displacement and suturing in the mid-line are much easier but care must be taken to avoid the formation of a fistula towards the front of these flaps.

A similar operation, but using two shorter flaps and permitting division of the greater palatine arteries with less risk of devitalising any part of the flaps, is known as the 'Wardill Operation'. This method described by Wardill of Newcastle, is sometimes called the ' $V-Y$ ' procedure since the shape of the incision at first outlines a V and then as the flaps slide backwards, come more to resemble a $\mathrm{Y}$.

Occasionally in a narrow cleft where the palate is already long, and favourable in other respects, the edges of the cleft may be paired as previously described and joined by stitches in the mid-line with little or no relaxing or releasing at the sides.

Carefully planned repairs of soft palate clefts only, should yield between eighty and one hundred percent normal speech.

\section{B. ClEFT SOFT PALATE AND A VARI-}

ABLE AMOUNT OF HARD PALATE. e.g. two-thirds or three-quarters cleft but still with the alveolus intact i.e. no 'gap in the gum'. The vomer, covered with mucous membrane, is normally well exposed and one can look into the naso-pharynx through the cleft in the palate. It is still possible to use the Langenbeck operation for these clefts but one of the best procedures is the so called 'Four Flap' operation of Wardill which uses two posteriorly based flaps for the main part of the repair and two smaller flaps based on the front of the hard palate, behind the teeth, to close the extreme front of the cleft and avoid a fistula in so doing.

Cuthbert has also designed an operation for this type of cleft ... particularly for use when the vault of the palate is high and changes its direction suddenly as the cleft is traced from front to back. This operation is of the three-flap variety and avoids the risk of fistula . . . particularly at the hard/soft junction- an area notorious for fistula for- mation following a progressive build up of tension while stitches are being put in.

Cuthbert's operation consists of using a long flap from one side and dividing the other side of the cleft into two flaps, one based on the front and the other on the back. The long flap is made to follow a curved course across the cleft, from side to side and in doing so crosses in between the two short flaps which are stitched to it. This gives a very long, mobile repair and minimises very greatly the effects of any shrinkage or contracture from back to front.

\section{COMPLETE ClEFTS . . . UNILATERAL OR BILATERAL . . usually associated with a cleft lip as well.}

There is, of course, a gap in the gum and a cleft lip is generally present as well.

An approach originally described by Dorrance, has several advantages in dealing with the difficult region at the front of the hard palate. The method may apply to complete, unilateral and bilateral clefts. A flap of mucosa from the vomer (or flaps from both sides of this partition in a bilateral cleft) is mobilised and its free edge moved across to be tucked under a raw edge prepared in the un-united margin of the hard palate part of the cleft.

When this has healed, almost the whole of the hard palate has been closed by the use of nasal lining only. The remaining part of the problem now resembles the closure of a cleft which has involved the soft palate alone.

Factors influencing the success of surgery are usually those of timing and technique. Timing in the sense of operating in the optimum period, includes consideration of general health and weight in relation to age. Timing must give consideration to the orthodontist - he must have started work early enough and have had long enough to have achieved maximum moulding before superadded surgical movement of soft tissues is undertaken. The speech therapist's orientation to timing must include the problem of whether or not the patient's operation has been delayed for so long that bad speech habits are in danger of becoming heavily imprinted on the brain. There may be danger from previous inexpert speech treatment elsewhere.

No amount of palate and lip closing, how- 
ever expertly done, can rectify serious mental blocks to normal speech. Such cases call for the highest degree of understanding and skill in a speech therapist.

As a generalisation it seems reasonable to say that fewer children with early adequate repairs of cleft palates need speech therapy than do those whose repairs are delayed until a fair-sized collection of badly pronounced words is in daily use.

Faulty surgical techniques are often perpetuated by operators who have been repairing cleft palates for many years and acquired experience without wisdom. The surgeon who is to achieve a high standard of results in his work, must be ruthless in his criticism of himself, and whenever an operation is unsuccessful, look first to himself and much later to the patient or instruments or type of operation for the cause of failure.

Briefly the surgeon must strive for a long mobile palate closed without perceptible tension, without rough handling of muscle and too severe an interference with blood supply.

The swelling following the operation produces a marked degree of stiffness of the palate. This may persist in some mild form for weeks or months. For this reason one frequently suggests that no speech therapy should be started for about three months and during this time attention should not be drawn to the child's speech. The child should be allowed to make attempts to speak in the same way as any normal child - by imitation of the parents and older children.

Whenever the parents are able to show an appreciation of the principles underlying treatment these should be explained to them.

The child himself, should never if possible, be allowed to feel that he is any different from other children. If and when any embarrassing situation arises - usually by a reference to the lip scar or speech peculiarities - the child should be encouraged to reply at once, if he is old enough, saying that he has had an operation and is getting better.

Several residual problems arise - some in the form of questions from speech therapists and parents. One of these problems is the occasional doubt as to whether speech therapy should be given in the presence of a fistula - can it be harmful in such cases?
The answer to this may depend on the site of the fistula and the intensity of therapy. Intensive efforts to master the technique of using the tongue to close off an anterior fistula, while still trying to produce normal speech with the rest of the palate and tongue, may produce a confused state of mind about certain sounds if an obturator is inserted later, or the fistula closed by a further operation. If an early operation or closure by obturator is not possible, it may be better to ignore wrong sounds produced by an anterior defect - if the rest of the anatomy is functioning reasonably well.

A fistula further back - the common site in many repairs is the junction of hard and soft palates - may not need any special therapy at all since its closure may be effected by ordinary movements of the tongue and by muscle movements of the palate in which it exists.

Incidentally, it is most unlikely that speech therapy, if started more than two weeks after a successful operation, would ever cause breakdown of a surgical repair.

Removal of tonsils and adenoids in a cleft palate patient is usually a factor against normal speech rather than for it. Unless the evidence for the removal of tonsils is very strong this operation should be avoided. If it has to be done this should be at least six to twelve months after the repair of the palate. The tonsils should be removed with special care and gentleness by an Ear Nose and Throat surgeon who is familiar with the fac. tors responsible for normal palate function in speech. Great efforts should be made to retain the adenoids as they may play a vital part in avoiding nasal escape.

Plastic surgeons are often asked to predict the chances of normal speech. Many clinics claim eighty per cent of normal speech after cleft palate repairs. There is probably more of the exceptional than the usual in this figure. It is probably safe to say that, with a child who is mentally normal, repairs of clefts of the soft palate only should yield normal speech in over eighty per cent of cases; repair of other clefts should yield normal speech in over fifty per cent of cases.

Post operative examination of the patient should not lead to judgements on the grounds 
of appearance of the patient's repaired palate. An ugly asymmetrical repair may be found in a patient with completely normal speech, and a palate that looks very close to the normal anatomy may produce poor speech. The function is more important than the apparent structure.

To return briefly to the question of obturators: can they ever do harm? It depends on what one means by "harm". A mechanically unsound obturator may cause dangerous ulceration by friction and pressure. A loose obturator or one which is too small because of the rate of growth of the patient may cause peculiar defects and the rest of the child's speech may be harmed by strenuous struggles by parents and speech therapists when all that is needed is a new obturator. This point should be checked repeatedly as the child grows.

One type of obturator worthy of special mention is that which is made with a very thick centre section, protruding downwards towards the middle third of the tongue. This sometimes has the effect of forcing the patient to move the tongue away to produce certain sounds adequately. If the design is correct, the tongue may be forced backwards and a more effective naso-pharyngeal closure produced - resulting in reduced nasal escape.

Mention should be made of the problem of sub-mucous clefts. These are not rare and prove well the point that more than mere closing, in the mechanical sense, of a hole or a cleft is required for good or normal speech. A patient with a sub-mucous cleft has cleft palate speech, yet when his mouth is opened the palate at first appears intact. A strong light will reveal that the centre line of the palate - particularly the soft palate - has the appearance of a thin greyish strip. This area consists of two layers of lining only (oral and nasal) with no muscle in between to complete the sandwich.

When an attempt is made to speak or produce a vowel sound the muscle either side of this thin area pulls upwards and backwards, but also 'outwards towards the side wall of the pharynx. Normal closure is not possible and cleft palate speech results. There can hardly be a better illustration of the importance of a functioning palate as opposed to a palate which is merely closed.
Median Cleft lip - upper or lower - is so rare that it barely deserves a mention. It is amenable to treatment by the application of standard principles.

Cleft palates are associated with several other conditions, two of which are not uncommon:

1. The Pierre Robin Syndrome.

2. Acrocephalo-Syndactyly.

\section{The Pierre Robin Syndrome.}

This patient has difficulty in feeding; choking and going blue from birth. On examination the lower jaw is small and very far back. So is the tongue, so that its muscle mass may rise up into the naso-pharynx, block this cavity (partly) and orally the entrance to the larynx. There is a cleft soft palate. Normal co-ordination between breathing and swallowing is not present and fluid may enter the child's lungs. This is dangerous and may prove fatal. Early treatment in hospital is essential, and there may be a case for early use of obturators, or even the rare method of an early closure of the cleft palate which may force the tongue to assume a more normal position. If all goes well the lower jaw should grow forward during the early years of life.

This deformity is typified by the description of it as "Andy Gumpism" or "The Chinless Wonder".

\section{Acrocephalo-Syndactyly.}

This is the label given to a child born with a tall skull, flattened from back to front, with a posterior cleft palate and fused fingers and toes.

Little has been said about the intelligence of the patient. This is not because it is unimporant but because little is known of its significance. Individuals vary greatly, but there is reason to believe that the more intelligent the patient the more subtle can be the teaching. There is a good deal of resemblance to some of the problems of hand surgery. Here too, the better the intelligence of the person, the more likely one is to achieve subtle movements. So it is with the palate and its fine structure - linked strongly to the brain above, inviting us never to be satisfied nor to lack criticism of our own efforts as long as there is the chance of giving our patient contact with his fellows by means of normal speech. 


\section{SUMMARY}

It is at present believed that one person alone cannot carry out the best possible treatment of the patient with a cleft lip and palate.

A good team consists of three groups:-

1. Plastic Surgeons and Nurses.

2. Orthodontists.

3. Speech Therapists.

About $20 \%$ of all cleft lip and palate patients have a family history of this condition. Of the remaining $80 \%$ a large proportion are born into families in which malnutrition is prevalent. The role of virus and other infections is uncertain. Until more is known of the effect of steroids, these should probably only be given to pregnant women with the greatest caution and fullest consultation - particularly in the first three months of pregnancy.

An average overall incidence of the deformity is still about one in a thousand births.

An initial treatment plan may be made in the Maternity Hospital. The Orthodontist can begin moulding the alveolar contour with a small splint attached by elastic bands to a webbing headcap. Subsequent operations are generally easier and more successful.

For classification prior to operation, it may be clearer to substitute a brief standard description rather than the ordinary textbook labels.

Hare-lip and cleft palate operations are rarely, if ever, emergencies - patients with even the severest forms of clefts can reach an otherwise healthy adult state with little or no treatment - although this should never happen in modern surroundings.

There is no one age believed to be the best for either lip or palate repair - world opinion still differs on this subject.

A general plan suggests that good results follow lip repair after the age of about three months and palate repair before the age of two years. There is some evidence for less interference with growth in the middle third of the face if the palate operation is less radical and/or delayed until the age of four years.

Lip repair aims at a fine white scar with nostril floors on the same horizontal level and the nostril base at the same distance from the mid-line on each side of the columella. The red margin should form a smooth line from right to left without any "steps" and with the same depth of mucous membrane on either side: the sides of the cleft should be of equal length.

The patient is usually in hospital for about ten days.

The prime aim of cleft palate repair is normal speech. It is believed that this is approached by a repair which produces a long, mobile soft palate with good muscular union. The soft palate should play a major role in closing off the oro-pharynx from the nasopharynx during speech.

For cleft soft palate only, the Langenbeck operation is not as satisfactory as the V-Y or Wardill type operation.

For more extensive clefts, but with the alveolus still intact, use may be made of the Wardill "four-flap" operation with a contribution from the mucous membrane of the vomer or septum.

One of the best methods of ensuring a really long palate with minimal risk of a fistula, is the Cuthbert "three-flap" operation. The two posterior flaps are of unequal length and the hard palate repair includes a short anteriorly based flap.

Repair of complete clefts, unilateral or bilateral, may include extensive use of the mucous membrane on either side of the vomer as a first stage. If this maneouvre is successful, the operation for the second stage in a few months time is reduced to the closure of the soft palate only.

Factors influencing the success of surgery are mostly matters of timing and technique - provided the patient is correctly assessed and is fit for operation. Timing and technique are important in the work of all three groups mentioned at the outset.

Generally fewer children need speech therapy if repairs are early and adequate. The child whose operation is delayed long enough to allow the accumulation of a fair sized collection of badly pronounced words will almost always have difficulty in attaining normal speech. 
Whenever the parents are able to show an appreciation of the principles underlying treatment, these should be explained to them.

The start of speech therapy may safely be delayed for weeks or even up to three months if swelling and scarring in the newly repaired palate take a long time to settle. At this time it may be well to allow he child to try and speak without correction - merely allowing the normal method of learning by imitation of adults and older children.

Speech therapy is rarely likely to be harmful at any stage. A possible hazard is intensive training in using the tongue to develop and control sounds in the presence of an anterior fistula while still trying to produce normal speech with the rest of the tongue and palate.

It is unlikely that speech therapy started more than two weeks after operation could cause damage.

Tonsils should only be removed, in cleft palate cases, by an operator with knowledge of the problems of cleft palate repair. Adenoids should be left whenever possible.

Although many clinics claim $80 \%$ normal speech after cleft palate repair, $50 \%$ is probably a good indication of a correct approach by a competent team.

The post operative appearance of the palate may bear no relation to the quality of the speech produced.

Obturators may be uncomfortable and even harmful if their fitting and maintenance are not submitted to frequent checks.

Obturators of a special kind, with thick centre sections may, in some cases, help to displace the tongue in a favourable manner.

Sub-mucous clefts are not rare and, although they present the appearance of a closed palate, the muscles are not attached in the mid-line and pull away between the layers of oral and nasal mucous membrane during speech. This failure of normal action is partly, responsible for the "cleft palate" speech produced by these patients.

Median cleft lip is rarely seen.

Two abnormalities associated with varying degrees of post-alveolar clefts are:-

(i) The Pierre Robin Syndrome - charac- terised by a receding lower jaw and serious episodes of chocking when feeding the new born child is attempted.

(ii) Acrocephalo-Syndactyly is a condition of a tall skull, flattened from before backwards in a child with fused fingers and toes and a posterior cleft palate.

These conditions are, of course, congenital.

The more intelligent the patient, the more subtle and hopeful can be the teaching.

\section{OPSOMMING}

Dit word vandag algemeen aangeneem dat een persoon alleen nie die beste behandeling moontlik aan pasiënte met gesplete lip en verhemelte kan gee nie. Die span sal uit drie groepe bestaan:-

(1) Plastiese Sjirurge en Verpleegsters.

(2) Orthodontiste.

(3) Spraakterapeute.

Omtrent $20 \%$ van alle gesplete lip en verhemelte pasiënte het 'n familiegeskiedenis van hierdie toestand. Van die orige $80 \%$ kry ons 'n groot aantal pasiënte in families waar ondervoeding voorkom. Die rol wat virus en ander infeksies speel is onseker. Totdat die effek van steroides meer bekend is, behoort dit baie versigtig en onder deeglike toesig alleenlik, aan swanger vrouens toegedien te word - veral gedurende die eerste drie maande van swangerskap.

Hierdie gebrek kom gemiddeld een uit 'n duisend gevalle voor.

Die aanvangsbehandeling kan al in die Kraaminrigting plaasvind. Die orthodontis begin om die alveolarelyn te vorm met 'n klein spalkie, wat met rekbande aan 'n weefselagtige mus vas is. Die daaropvolgende operasies is dan gewoonlik makliker en meer suksesvol.

Om meer duidelikheid te verkry in verband met klassifikasie voor die operasie, mag dit beter wees om 'n kort standaard beskrywing, eerder as die gewone handboekbenaminge te gebruik.

Operasies vir haaslip en gesplete verhemelte is selde, indien ooit, noodgevallepasiënte, met selfs die ergste graad van splete, kan andersinds nog 'n gesonde volwassenheid bereik, met weinig of geen behandeling nie - hoewel dit nooit vandag 
behoort te gebeur nie.

Daar is nie 'n spesifieke ouderdom, wanneer dit die beste is om die herstelwerk te doen nie - gesaghebbendes verskil nog oor die onderwerp.

Die algemene idee is dat die beste resultate gekry word wanneer herstelwerk aan die lip na die ouderdom van drie maande gedoen word en aan die verhemelte, voor twee jaar. Daar is gegewens wat bewys dat die groeiproses, van die middelste derde van die gesig, minder gesteur word, as die operasie op die verhemelte nie baie groot is nie, en/of as dit uitgestel word tot die ouderdom van omtrent vier jaar.

Die doel van lipherstellingswerk is om 'n fyn wit litteken te kry, met die vloer van die neusvleuels op dieselfde horisontale vlak en die basis van die neusvleuels behoort ewe ver van die middellyn aan elke kant van die kollumella af te wees. Die rooi lyn moet ook egalig wees van links na regs, sonder enige "trappies" en die slymvlies moet dieselfde diepte hê aan elke kant: die kante van die spleet behoort ewe lank te wees.

Die pasiënt bly gewoonlik vir tien dae in die hospitaal.

Die hoofdoel van die herstelling van 'n gesplete verhemelte is om normale spraak te verseker. Om dit te bereik behoort die operasie 'n lang, beweeglike sagteverhemelte met goeie spierverbindings te lewer. Die sagte verhemelte is belangrik vir die afsluiting tussen de neus-keelholte en mond-keelholte gedurende spraak.

Wanneer alleenlik aan die sagteverhemelte gewerk word, is bevind dat die V-Y of Wardill operasie meer bevredigend is as die Langenbeck operasie.

Die Wardill ,vier-flap” operasie, met behulp van die septum se slymvlies, kan ook gebruik word, by groter splete, maar moet die alveolare rif nog onbeskadig wees.

Een van die beste metodes om 'n lang verhemelte, met 'n minimale gevaar van 'n fistel, te verseker, is die Cuthbert "drie-flap" operasie. Die twee agterste lappe is nie ewe lank nie en die herstelling van die hardeverhemelte sluit die derde lap, wat voor vas is, in.

Die eerste stadium van die herstelling van totale splete, uni- of bilateraal, sluit 'n grootskaalse gebruik van die slymvlies, aan beide kante van die septum, in. As dit suksesvol is, sal die operasie in die tweede stadium, na 'n paar maande, net die sluiting van die sagteverhemelte beteken.

Twee faktore beïnvloed gewoonlik die sukses van die sjirurgie: tydsberekening en tegniek- op voorwaarde dat die pasiënt reg opgesom en geskik vir operasie is. Tydsberekening en tegniek is belangrik by al drie die bogenoemde groepe.

Oor die algemeen het minder kinders spraakterapie nodig as die operasies vroeg en voldoende uitgevoer word. Wanneer die operasie gelaat word totdat die kind al 'n hele aantal woorde verkeerd uitspreek, sal so 'n kind omtrent altyd sukkel om normale spraak aan te leer.

Wanneer dit duidelik is dat ouers die grondbeginsels van die behandeling verstaan moet dit aan hulle verduidelik word.

Daar sonder moeilikheid van 'n paar weke tot drie maande gewag word voordat met spraakterapie begin word, as die swelsels en littekens in die verhemelte lank neem om te genees. Gedurende hierdie tyd is dit soms gewens om die kind toe te laat om te probeer praat, sonder dat hy behandeling ontvang slegs om hom die geleentheid te gun om onder die normale omstandighede, van nabootsing, te leer praat.

Spraakterapie is gewoonlik nie skadelik in enige van die stadiums nie. Die enige moeilikheid is intensiewe behandeling om die tong te gebruik om spraakklanke te vorm en beheer met 'n fistel voor, terwyl normale spraak met die res van die tong en verhemelte gevorm word.

Dit is onwaarskynlik dat enige gevaar bestaan as daar met spraakterapie begin word langer as twee weke na die operasie.

In die geval van 'n gesplete verhemelte, behoort mangels alleenlik deur 'n dokter, met kennis van die probleme wat spruit uit die herstelling van 'n gesplete verhemelte verwyder te word. Indien moontlik, behoort die adenoỉde nie verwyder te word nie.

Alhoewel baie klinieke daarop roem dat hulle $80 \%$ normale spraak kry na operasies aan 'n gesplete verhemelte, is $50 \%$ 'n goeie 
aanduiding van die regte benadering deur 'n bekwame span.

Die voorkoms van die verhemelte na die operasie is geen aanduiding van die kwaliteit van de spraak wat gevorm sal word nie.

Obturators kan ongemaklik en selfs gevaarlik wees as hulle nie pas nie, en as die versorging nie gedurig gekontroleer word nie. 'n Sekere soort obturator, met 'n dik middeldeel, mag in sommige gevalle help met die plasing van die tong.

Splete, wat verberg word deur 'n normale slymvlies in die mond en neus, is nie 'n rare verskynsel nie en omdat die spiere, op die middellyn, nie verbind is nie, trek hulle uit mekaar as die persoon praat. Hierdie gebrek aan normale aksie veroorsaak die tipe spraak wat by ' $n$ persoon met 'n gesplete verhemelte gevind word.

'n Sentrale spleet kom selde voor.

Twee abnormaliteite word geassosieer met verskillende grade van splete wat agter die alveolare rif voorkom:- (i) Die Pierre-Robin Sindroom - herkenbaar aan 'n kort kakebeen en ernstige aanvalle van verstikking wanneer die pasgebore baba gevoed word.

(ii) Akrokefalo-sidaktilie is 'n toestand van 'n kort kakebeen en 'n lang kopbeen wat plat van voor af agtertoe loop, by 'n kind met vingers en tone wat saamgesmelt is en 'n gesplete verhemelte agter in die mond.

Hierdie toestande is natuurlik aangebore.

Hoe intelligenter die pasiënt is, hoe meer subtiel en veelbelowend is die onderrig.

\section{Acknowledgements}

The author wishes to thank Mr. J. B. Cuthbert, Head of the Plastic Surgery Unit of the Johannesburg Group of Hospitals, for many stimulating discussions and demonstrations; also Professor Dreyer and Dr. G. Gavron of the Dental and Oral Hospital for information from their Departments.

In addition thanks are due to members of the Staff of the Speech Therapy Department of the Johannesburg General Hospital for their co-operation in assessing and handling many patients. 